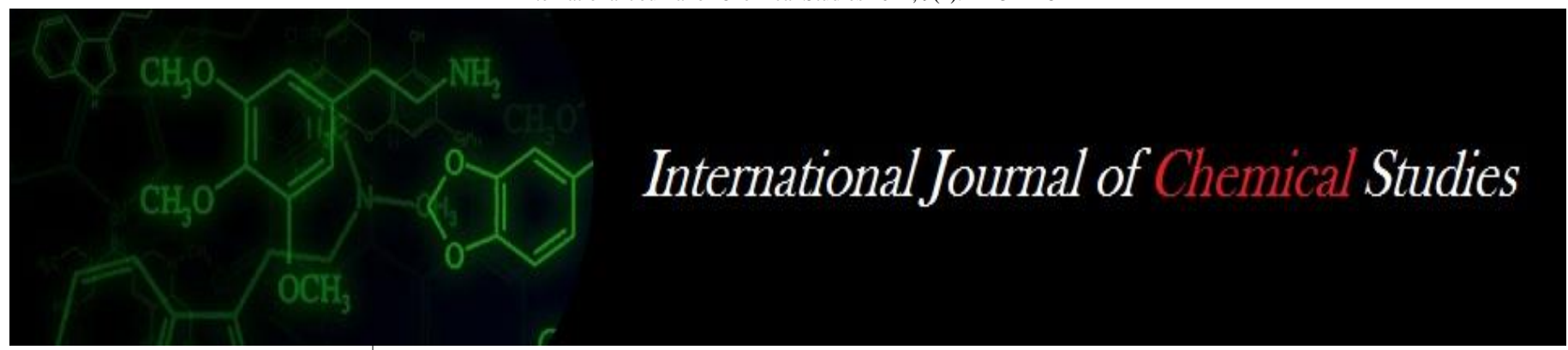

P-ISSN: 2349-8528

E-ISSN: 2321-4902

www.chemijournal.com

IJCS 2021; 9(1): 2423-2425

(C) 2021 IJCS

Received: 15-11-2020

Accepted: 20-12-2020

Jayesh Shesh

Department of Agronomy,

College of Agricultur, IGKV,

Raipur, Chhattisgarh, India

Dr. Santosh Kumar Jha

Department of Agronomy,

College of Agricultur, IGKV,

Raipur, Chhattisgarh, India

Ritesh Kumar Singh

Department of Agronomy,

College of Agricultur, IGKV,

Raipur, Chhattisgarh, India

Supriya Thakur

Department of Agronomy,

College of Agricultur, IGKV

Raipur, Chhattisgarh, India

Corresponding Author:

Jayesh Shesh

Department of Agronomy,

College of Agricultur, IGKV,

Raipur, Chhattisgarh, India

\section{Effect of de-topping and nitrogen doses on economics of maize (Zea mays L.) Varieties}

\author{
Jayesh Shesh, Dr. Santosh Kumar Jha, Ritesh Kumar Singh and Supriya \\ Thakur
}

DOI: https://doi.org/10.22271/chemi.2021.v9.i1ah.11592

\begin{abstract}
The experiment was conducted at research Farm, Indira Gandhi Agriculture=University, Raipur (C.G.) during Kharif 2018 to study the effect of de- topping and nitrogen levels on economics of maize (Zea mays L.) with two maize varieties (African tall and hybrid 25K55) practicing de-topping and no detopping in main plots and four nitrogen levels in sub plot under split plot design and replicated thrice. The results of experiment on response of de-topping and nitrogen levels revealed that the minimum cost of cultivation Rs 31725 without de-topping in African tall, maximum gross return Rs ha- ${ }^{-1}$ was found in African tall with de-topping Rs 85478 and maximum net return Rs 53537 and B:C ratio 2.65 was recorded highest when no de-topping was done in African tall. Similarly, all these characters were also superior under treatment receiving $150 \mathrm{~kg} \mathrm{~N} \mathrm{ha}^{-1}$. The least value was obtained in unfertilized treatment.
\end{abstract}

Keywords: Topping, de-topping, nitrogen levels

\section{Introduction}

Maize (Zea mays L.) popularly known as corn or makka is one of the important cereal crops in world agriculture economy both as food for man and feed for animals. Maize is one of the most versatile crop with wide adaptability in agro-ecologies with maximum biomass production ability in short duration. It has highest genetic potential among food grains crops. In india maize is third most important food crop after rice and wheat in addition to staple food for humans and feed for animals. Among non-legumes fodders, maize is good source of starch, neutral detergent fibre (38-41\%), acid detergent fibres (23-25\%), lipid (5\% oils), crude-protein $(8-10 \%)$ therefore considered as energy efficient crop for livestocks.

It is a $\mathrm{C}_{4}$ plant, having high fodder production ability in short duration of time. Maize is cultivated through the year in different parts of country for various purpose including grain, baby corn fodder, green cobs, pop corn etc. In India maize is grown in 9.5 million hectare area with production of 26.63 million tones. In Chhattisgarh it is cultivated in 226.79 hectare area with an average yield of $2458 \mathrm{~kg} \mathrm{ha}^{-1}$. Its cultivation is confined to Ambikapur, Jashpur, Bilaspur, Raigarh, Raipur, Durg, Kanker, Jagdalpur and Dantewada districts of Chhattisgarh. It is an important crop to develop standard agronomic practices to get maximum productivity. De-topping is one such culture operation practiced by maize growers. De-topping is such a cultural practice in which the apical or terminal portion of plant is removed from nodes above cobs i.e. leaving one or two leaves with aim to increase yield by controlling lodging, increasing light interception, increasing nutrient uptake, diverting plant nutrient to developing reproductive part (cobs) which in turn improves source to sink efficiency and resulting better cobs development.

Hence the present study was carried out with an objective to study the effect of de-topping and nitrogen levels on yield of maize (varieties).

\section{Material and Methods}

The experiment was conducted during kharif, 2018 at Instructional cum Research farm, College of Agriculture, Indira Gandhi Krishi Vishwavidyalay, Raipur (C.G.) with proper irrigation and drainage facilities. The institute is situated at Raipur in the central part of Chhattisgarh, climatologically known as "Chhattisgarh Plains" and geographically farm lies in between $21^{\circ} 16^{\prime} \mathrm{N}$ latitude and $81^{\circ} 26^{\prime}$ E longitude at altitude of 289.56 meters above the mean sea level (MSL), and falls under central plateau. 
According to soil analysis, the soil of the experimental site was sandy loam in texture. The soil was neutral in reaction $\mathrm{pH}$ (7.8) with electrical conductivity (EC) in the safer range $(0.21$ $\left.\mathrm{dSm}^{-1}\right)$, low in organic carbon $(0.58 \%)$ and available $\mathrm{N}(229.5$ $\left.\mathrm{kg} \mathrm{ha}^{-1}\right)$ but medium in available phosphorus $\left(16.3 \mathrm{~kg} \mathrm{ha}^{-1}\right)$ and medium in potassium $\left(272.02 \mathrm{~kg} \mathrm{ha}^{-1}\right)$. A uniform dose of $\mathrm{P}_{2} \mathrm{O}_{5}\left(50 \mathrm{~kg} \mathrm{ha}^{-1}\right)$ and $\mathrm{K}_{2} \mathrm{O}\left(40 \mathrm{~kg} \mathrm{ha}^{-1}\right)$ were applied in Single super phosphate (SSP) and muriate of potash (MOP), respectively and nitrogen was applied in three splits, $40 \%$ at basal, $30 \%$ at knee high stage and $30 \%$ at tasseling stage was scheduled through urea. The experiment was laid out in split plot design with three replications and comprising sixteen treatment combinations with de-topping \& no-detopping in maize varieties in main plots and four nitrogen levels 0,50 $\mathrm{kg}, 100 \mathrm{~kg}$, and $150 \mathrm{~kg} \mathrm{~N} \mathrm{ha}^{-1}$ in sub plots with $2.7 \times 3 \mathrm{~m}$ net plot area.

\section{Result and Discussion \\ Cost of cultivation}

The cost of cultivation African tall with de-topping, was Rs 35475 and without de-topping was Rs 31725 . However, the cost of cultivation in hybrid $25 \mathrm{~K} 55$ was Rs 38255 with detopping and Rs 34535 without de-topping. Similar results are even recorded by Manju Bhargavi et al. (2017)

Among nitrogen levels, minimum cost of cultivation was with control plot (Rs $30396 \mathrm{ha}^{-1}$ ) which is increase by increasing application of nitrogen being highest under $150 \mathrm{~kg} \mathrm{~N} \mathrm{ha}^{-1}$ (Rs 37193 ha $^{-1}$ ).

Table 1: Cost of cultivation as influenced by de-topping and nitrogen levels

\begin{tabular}{|c|c|c|c|c|}
\hline $\begin{array}{c}\text { Treatments } \\
\text { Main plot: DT and No DT }\end{array}$ & $\begin{array}{c}\text { Cost of } \\
\text { cultivation }\end{array}$ & $\begin{array}{c}\text { Gross } \\
\text { return }\end{array}$ & $\begin{array}{c}\text { Net } \\
\text { return }\end{array}$ & $\begin{array}{c}\text { B:C } \\
\text { Ratio }\end{array}$ \\
\hline Fodder type: African tall & & & & \\
\hline $\mathrm{D}_{1}$ : No De -topping & 31725 & 85262 & 53537 & 2.65 \\
\hline $\mathrm{D}_{2}$ : De-topping & 35475 & 85478 & 50002 & 2.37 \\
\hline Grain type: Hybrid 25K55 & & & & \\
\hline $\mathrm{D}_{3}:$ No De-topping & 34535 & 79491 & 44955 & 2.26 \\
\hline $\mathrm{D}_{4}$ : De-topping & 38285 & 78350 & 40065 & 2.01 \\
\hline $\mathrm{S}$. Em \pm & & 1692 & 1692 & 0.1 \\
\hline $\mathrm{CD}(\mathrm{P}=0.05)$ & & 5853 & 5853 & 0.19 \\
\hline $\begin{array}{c}\text { Sub plot: Nitrogen levels N }(\mathbf{k g} \\
\text { ha-1) }\end{array}$ & & & & \\
\hline $\mathrm{N}_{1}: 0$ & 30396 & 47626 & 17230 & 1.58 \\
\hline $\mathrm{N}_{2}: 50$ & 35895 & 69744 & 33849 & 1.95 \\
\hline $\mathrm{N}_{3}: 100$ & 36537 & 96252 & 59715 & 2.65 \\
\hline $\mathrm{N}_{4}: 150$ & 37193 & 114959 & 77766 & 3.11 \\
\hline $\mathrm{S}_{1}$ Em \pm & & 1224 & 1224 & 0.04 \\
\hline $\mathrm{CD}(\mathrm{P}=0.05)$ & & 3572 & 3572 & 0.11 \\
\hline Interaction $\mathrm{DXN}$ & & $\mathrm{NS}$ & $\mathrm{NS}$ & $\mathrm{NS}$ \\
\hline
\end{tabular}

\section{Gross return}

Maximum gross return $\mathrm{Rs} \mathrm{ha}^{-1}$ was found in African tall with de-topping ( $\mathrm{Rs} 85478$ ) as as compare to no de-topping (Rs 85262 ) this may be due to the additional income from the detopped portion as green fodder. Grain yield was found higher in hybrid variety $25 \mathrm{~K} 55$ as compared to fodder variety African tall, But gross return was higher in fodder variety African tall this may be due to high rate of fodder maize seed as compared to grain of hybrid $25 \mathrm{~K} 55$, varied nitrogen levels increases the gross return as higher return is registered in 150 $\mathrm{kg} \mathrm{N} \mathrm{ha}{ }^{-1}$ (Rs $114959 \mathrm{ha}^{-1}$ ). The interaction effect of detopping and nitrogen levels showed non-significant effect on gross return.

\section{Net monetary returns (NMR)}

Net income from investigation after deducting all expenses from the gross income generated by investment is net monetary returns. The net monetary return (NMR) varied due to de-topping and nitrogen levels. Net monetary return was found maximum with fodder variety (Rs 50002) the difference between de-topping and no de-topping was (Rs 3535) which was higher in no de-topping this may be due to labor cost of de-topping. Net monetary return was less in hybrid variety $25 \mathrm{~K} 55$ as compared to fodder variety due to high demand and unavailability of fodder maize seed African tall gives better seed cost in market.

Varied nitrogen levels increases the net monetary return due to increase in marketable grain yield. The higher net return was registered with application of $150 \mathrm{~kg} \mathrm{~N} \mathrm{ha}^{-1}$ (Rs 77766 $\mathrm{ha}^{-1}$ ). However, minimum net return (Rs 17230) was registered in control plot with no nitrogen application due to minimum grain and straw yield. The interaction effect of detopping and nitrogen levels showed non-significant on net return.

\section{Benefit cost ratio}

Benefit cost ratio invested is an indication that attempts to summarize the overall value for money of a project it is the ratio of benefits received in terms of money. It is clear from the data presented in Table. 1 that benefit cost ratio invested differ due to de-topping and no de-topping the maximum B:C ratio (2.6) was recorded in fodder variety with no de-topping as compare to other main plot treatments. De-topping and no de-topping show marginal difference in both the variety in regards to the benefit cost ratio invested. This may be due to additional fodder yield obtain from de-topping treatment. Similar results were observed by Emran et al. (2014) ${ }^{[4]}$.

Higher monetary return per rupees invested was found in fodder variety African tall as compare to hybrid variety. The market value of green fodder and fodder seed are always high as compare to hybrid seed. Monetary return was found almost similar in de-topping and no de-topping practices. But in detopping farmer can obtain additional green fodder by cutting the upper portion just above the cob.

Among various nitrogen levels $150 \mathrm{~kg} \mathrm{~N} \mathrm{ha-1}$ recorded significantly maximum benefit cost ratio invested (3.11) as compare to other treatments. However, the minimum benefit cost ratio invested was recorded in unfertilized treatment (1.58) due to lowest grain and stover yield.

\section{Conclusion}

The findings of response of de-topping and nitrogen levels on economics of maize varieties, resulted that the maximum net monetary return (Rs 53537) was obtained from treatment no de-topping with African tall and the $\mathrm{B}: \mathrm{C}$ ratio of no detopping with African tall (2.65) which was at par with detopping with African tall (2.37).

\section{Reference}

1. Barimavandi AR, Sedaghathoor S, Ansari R. Effects of different defoliation treatments on yield and yield components in maize (Zea mays L.) cultivar of S.C.704. Australian Journal of Crop Science 2010;4(1):9-1.

2. Bhargavi MB, Reddy MM, Mukundam B. an economic analysis of maize (Zea mays L.) yield response to detopping practices 2016. www.environmentandecology.com/publication-volume372019 2262-2265, December 2016 
3. Chaudhary AN, Latif MI, Haroon, Ur-Rasheed M, Ghulam-Jilani. Profitability increase in maize production through fertilizer management and defoliation under rain fed cropping. Int. J of Bio. and Biotech 2005;2(4):10071012.

4. Emran SA, Haque KMS, Khaliq QA, Miah MY. Sourcesink manipulation and population density effects on fodder and grain yield of hybrid maize. Bangladesh Agronomy Journal 2014;17(1):59-66.

5. Jalilian J, Delkhoshi H. How much, leaves near the ear contribute on yield and yield components of maize. Crcetări Agronomiceîn Moldova 2014;2(158):5-12.

6. Pandey AK, Parakash V, Singh RD, Mani VP. Response of maize varieties to nitrogen levels and sulphydryl compounds. Crop Res 2000;9:28-33.

7. Rathika S, Velayudham K, Muthukrishnan, Thavaprakaash N. Effect of crop geometry and topping practices on the productivity of baby corn (Zea mays L.) based intercropping systems. Madras Agriculture J 2008;95(7-12):380-385. 